\title{
DAMPAK PELAKSANAAN PENGAJARAN MIKRO BERORIENTASI PADA PENGUASAAN MATERI TERHADAP KUALITAS MENGAJAR MAHASISWA PPL
}

\author{
Jeffry Handhika \\ Pendidikan Fisika, Fakultas Pendidikan Matematika dan IPA, IKIP PGRI Madiun \\ Email: jeffry.handhika@yahoo.com
}

\begin{abstract}
Abstrak
Pelaksanaan pembelajaran mikro berdampak pada kualitas pelaksanaan PPL di sekolah mitra. Model pembelajaran mikro perlu mempertimbangkan penguasaan materi mahasiswa dalam pelaksanaannya. Pada tahun 2012, mahasiswa diberikan kebebasan untuk memilih materi yang dikuasainya, sehingga secara tidak langsung penekanan terhadap penguasaan materi berkurang dan berdampak pada nilai rata-rata pemilihan materi ajar pada kegiatan PPL (2.75 untuk penilai guru dan 2.76 untuk penilai dosen) dan penguasaan materi pembelajaran (2,63 untuk penilai guru, dan 2,72 untuk penilai dosen) rendah dibandingkan dengan indiaktor lainnya. Pengajaran mikro yang berorientasi materi juga tidak membantu peningkatan kualitas pembelajaran mikro. Peningkatan kualitas matakuliah prasyarat pembelajaran mikro merupakan rekomendasi yang tepat untuk mengatasi permasalahan ini.
\end{abstract}

Kata Kunci: pembelajaran mikro, penguasaan materi, PPL

\section{Pendahuluan}

Istilah "microteaching" (pembelajaran mikro) mengacu pada praktek bagi mahasiswa di program studi pendidikan dengan melakukan kegiatan dan metode "mengajarkan" pelajaran kepada rekan sejawat untuk mendapatkan pengalaman dengan perencanaan pelajaran yang telah disusun (Bell:2007). Pembelajaran mikro merupakan prosedur yang dikembangkan di pendidikan guru untuk meningkatkan kemampuan mengajar calon guru (Arsal:2014), (Mergler \& Tangen:2010). Pengajaran mikro merupakan kegiatan pengajaran (peer teaching) yang bertujuan untuk mempersiapkan ketrampilan mengajar para mahasiswa agar memiliki wawasan dan pengalaman ketrampilan mengajar yang diperlukan untuk keperluan real teaching di sekolah yang tertuang dalam pedoman microteaching Unit Praktek Pendidikan (UPK:2011).

Pembelajaran mikro merupakan kegiatan pembelajaran yang dapat meningkatkan kemampuan pedagogik mahasiswa (Kartal et al:2012), peningkatan kepercayaan diri dan skill mengajar, dan penguatan karakter gaya mengajar calon guru (Donnelly \& Fitzmaurice:2011). Melalui kegiatan pembelajaran mikro, mahasiswa dituntut untuk berlatih membuat SSP, praktek mengajar secara langsung dihadapan rekan sejawat maupun dosen. Dalam pengajaran mikro (microteaching), secara spesifik mahasiswa diberi bekal (1) perancangan SSP, (2) praktek mengajar dengan berbagai model, metode, dan pendekatan, (3) serta praktek evaluasi pembelajaran dalam sekala laboratorium. Peserta dalam kegiatan pembelajaran mikro adalah mahasiswa yang menempuh matakuliah pengajaran mikro. Dalam satu kelompok mikro terdapat 7-8 mahasiswa, dan 1 dosen pembelajaran mikro. Pelaksanaan pembelajaran praktik pengajaran mikro telah dikembangkan oleh team UPK istitusi. Indikator penilaian pelaksanaan pembelajaran mikro meliputi: (1) perencanaan pembelajaran, (2) Pelaksanaan praktek pembelajaran yang tertuang dalam pedoman mikroteaching (UPK:2011). Pembelajaran mikro juga berdampak pada pembentukan sikap dan karakter mahasiswa (Spark \& Mc Callon:1974), (Donnelly \& Fitzmaurice:2011)., pembelajaran mikro membiasakan mahasiswa untuk membuat perencanaan pembelajaran dan melakukan refleksi kegiatan pembelajaran. Khusus di IKIP PGRI Madiun, juga diterapkan 
penggunaan seragam dan almamater untuk menunjukkan identitas keguruan.

Terdapat delapan indikator penilaian untuk perencanaan pembelajaran dan 12 indikator pelaksanaan praktik pembelajaran (UPK:2011). Indikator perencanaan pembelajaran meliputi : (1) kejelasan perumusan tujuan pembelajaran, (2) pemilihan materi ajar, (3) pengorganisasian materi ajar, (4) pemilihan sumber/media pembelajaran, (5) Kejelasan sekenario pembelajaran, (6) kerincian sekenario pembelajaran, (7) kesesuaian teknik dengan tujuan pembelajaran, (8) kelengkapan instrumen. Indikator pelaksanaan praktik pembelajaran meliputi: (1) memeriksa kesiapan siswa dalam melakukan kegiatan apersepsi, (2) menguasai materi pembelajaran dan menyampaikannya dengan jelas sesuai dengan hierarki belajar, (3) mengaitkan materi dengan realitas kehidupan dan pengetahuan lain yang relevan, (4) melaksanakan pembelajaran sesuai kompetensi (tujuan) yang akan dicapai, secara runtun dan sesuai dengan alokasi waktu yang direncanakan, (5) melaksanakan pembelajaran secara kontekstual dan menumbuhkan kebiasaan positif, (6) menguasai kelas, (7) menggunakan media secara efektif, efisien, dan menarik serta melibatkan siswa dalam pemanfaatannya, (8) Menumbuhkan keceriaan, antusisme dan partisipasi aktif siswa dalam pembelajaran, (9) menunjukkan sifat terbuka terhadap respons siswa, (10) memantau kemajuan belajar selama proses pembelajaran dan melakukan penilaian akhir sesuai dengan kompetensi, (11) menggunakan bahasa lisan dan tertulis secara jelas, baik dan benar serta dengan gaya yang sesuai, (12) Melakukan refleksi atau membuat rangkuman dengan melibatkan siswa, memberikan arahan, kegiatan atau tugas sebagai bagian remidi/pengayaan.

Pelaksanaan pengajaran mikro tahun 2012, diberikan 18 pertemuan dengan bobot 2 sks. Tidak semua pertemuan dilaksanakan praktek, pada pertemuan I didiskusikan tentang kontrak kuliah, pertemuan II sampai V, mahasiswa dibekali kemapuan dalam penyusunan SSP, kemudian dilanjutkan kegiatan praktek pengajaran mikro, dan 2 pertemuan digunakan untuk ujian pengajaran mikro (UTS dan UAS), sehingga efektif pelaksanaan SKS praktik pembelajaran mikro sejumlah 8 pertemuan. Pembelajaran mikro sangat penting guna mempersiapkan calon pendidik fisika melaksanakan praktek mengajar di lapangan. Kualitas pembelajaran mikro yang baik akan meningkatkan kualitas kegiatan PPL.

\section{Metode Penelitian}

Metode dalam penelitian ini adalah diskriptif, dengan menyajikan secara diskriptif data hasil pelaksanaan PPL dan melakukan evaluasi terhadap pelaksanaan pembelajaran mikro. Perubahan model pembelajaran mikro didiskripsikan dan dijelaskan pengaruhnya terhadap pelaksanaan PPL. Subjek penelitian ini adalah mahasiswa yang menempuh matakuliah pembelajaran mikro (7 mahasiswa) dan mahasiswa PPL tahun 2012 (4 orang), mahasiswa yang mengikuti pembelajaran mikro (8 mahsiswa) dan kegiatan PPL tahun 2013 (4 orang).

\section{Hasil Penelitian Dan Pembahasan}

Hasil pelaksanaan Praktik Pengalaman lapangan (PPL) tahun 2012 di sekolah menengah atas, diperoleh informasi bahwa rata-rata nilai perencanaan pembelajaran memberikan nilai rata-rata 2,78 untuk penilai guru dan 2,80 untuk penilai dosen, dalam sistem penilaian masuk dalam kategori nilai B, dengan rata-rata nilai terendah pada indikator 2 (Gambar 1). 


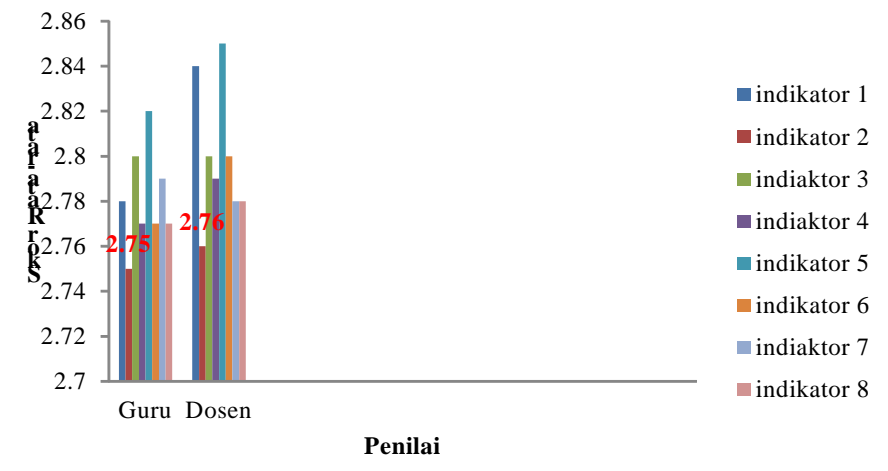

\section{Gambar 1. Rata-rata Nilai Perencanaan Pembelajaran Mahasiswa PPL}

Berdasarkan diskripsi data diatas, dapat diperoleh informasi bahwa indikator 2 (pemilihan materi ajar) memperoleh nilai terendah. Pada saat PPL (2.75 untuk penilai guru dan 2.76 untuk penilai dosen), mahasiswa belum dapat memilah materi yang harusnya diajarkan di level SMA dan SMP. Proses pembelajaran mikro pada tahun 2012, belum memberikan batasan materi yang jelas, karena belum ada perumusan learning Outcome (LO) yang spesifik. Pada tahun 2012, profil lulusan P. Fisika IKIP PGRI Madiun masih mencantumkan guru fisika secara umum, guru fisika SMP maupun SMA. Pada saat pembelajaran mikro, mahasiswa memilih materi SMP, sedangkan pada saat PPL, mereka ditempatkan di tingkat SMA. Temuan ini dapat dijadikan pertimbangan program studi dalam merumuskan LO, dan unit UPK dalam menentukan tempat PPL.

$$
\text { Rata-rata nilai pelaksanaan }
$$
pembembelajaran (Gambar 2) memberikan informasi bahwa penguasaan materi fisika mahasiswa fisika perlu ditingkatkan. Hasil ini sebenarnya berkaitan dengan nilai rata-rata rata nilai perencanaan pembelajaran PPL dan pelaksanaan pembelajaran mikro sebelumnya.

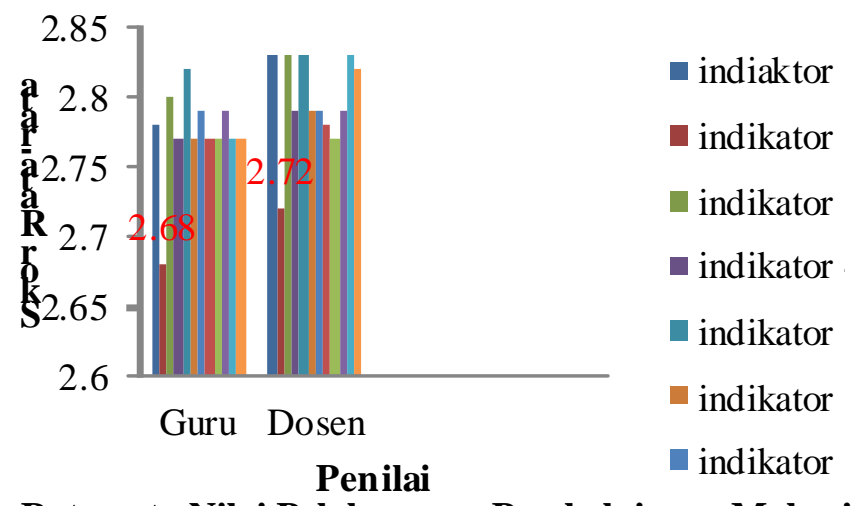

Gambar 2. Rata-rata Nilai Pelaksanaan Pembelajaran Mahasiswa PPL

Indikator 2 dalam pelaksanaan pembelajaran berkaitan dengan penguasaan materi pembelajaran dan penyampaiannya merupakan nilai rata-raya terendah $(2,63)$ untuk penilai guru, dan $(2,72)$ untuk penilai dosen. Hasil ini meberikan informasi bahwa dalam pelaksanaan PPL, mahasiswa tidak menguasai materi dengan baik. Hasil ini juga didukung dari hasil Tanya jawab dengan guru. Hasil ini tentunya juga tidak lepas dari pelaksanaan pembelajaran mikro, dimana penguasaan materi tidak menjadi prioritas utama, melatihkan kemampuan pedagogi dan pembebasan pemilihan materi ternyata berdampak pada rendahnya nilai PPL. Pada pembelajaran mikro semester berikutnya, dosen mencoba menitikberatkan kemampuan materi tanpa mengesampingkan kemampuan pedagogi dan penyusunan SSP.

\section{0 | Handhika, Dampak Pelaksanaan Pengajaran Mikro Berorientasi Pada...}


Pada pelaksanaan pembelajaran mikro tahun 2013, secara garis besar sama dengan pelaksanaan pembelajaran mikro tahun 2012, hanya saja dosen sudah menekankan penguasaan materi, terutama materi SMA. Mahasiswa tidak diberikan kebebasan pemilihan materi, disediakan 8 pokok bahasan untuk diundi, diambil pada saat mahasiswa akan melakukan kegiatan pembelajaran mikro. Hasil ini berdampak pada penurunan skor ratarata nilai pembelajaran mikro (Gambar 3).

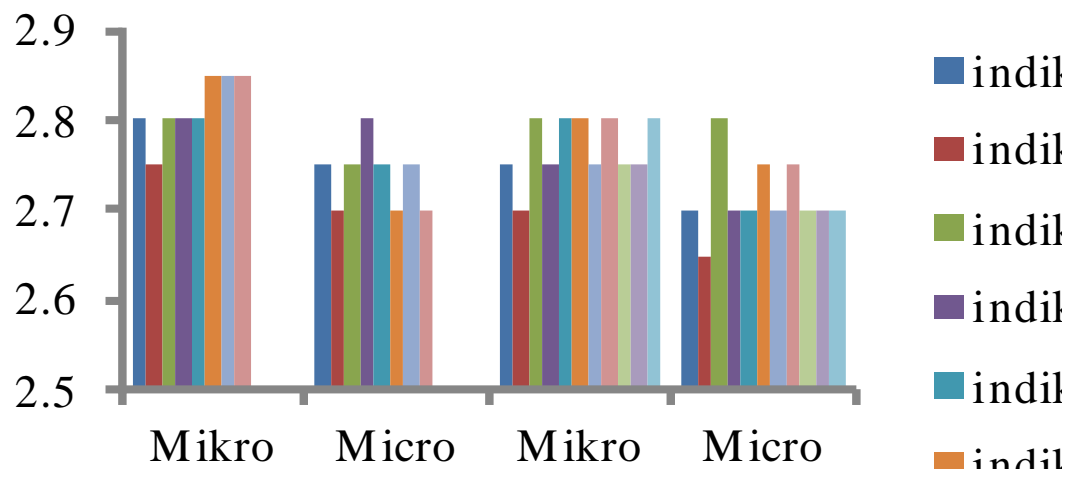

Gambar 3. Rata-rata Nilai Pelaksanaan Pembelajaran Mahasiswa PPL

Penekanan penguasaan materi berdampak pada kegiatan perencanaan dan pelaksanaan pembelajaran mikro. Mahasiswa lebih terkonsentrasi pada pembelajaran materi daripada penyiapan SSP. Pelaksanaan praktek mikro juga mengalami kendala Karena mahasiswa belum menguasai materi dengan baik walaupun sudah menyediakan waktu lebih untuk belajar materi. Perubahan model mikro yang berorientasi pada materi tidak merubah kualitas pembelajaran mikro maupun memperbaiki penguasaan materi mahasiswa. Direkomendasikan untuk memperkuat matakuliah prasyarat keilmuwan fisika (fisika dasar I, Fisika Dasar II, dan lainnya) dan matakuliah yang berkaitan dengan kemampuan pedagogik untuk meningkatkan kualitas pembelajaran mikro. Asumsi rekomendasi, jika matakuliah keilmuwan fisika dikuasai dengan baik, maka kualitas penguasaan materi akan lebih baik. Penguasaan materi tidak dapat diperoleh secara instan, butuh proses yang panjang dan terarah. Penetapan nilai minimum matakuliah prasyarat pembelajaran mikro dengan nilai "B" perlu segera diterapkan untuk menjaga kualitas lulusan.

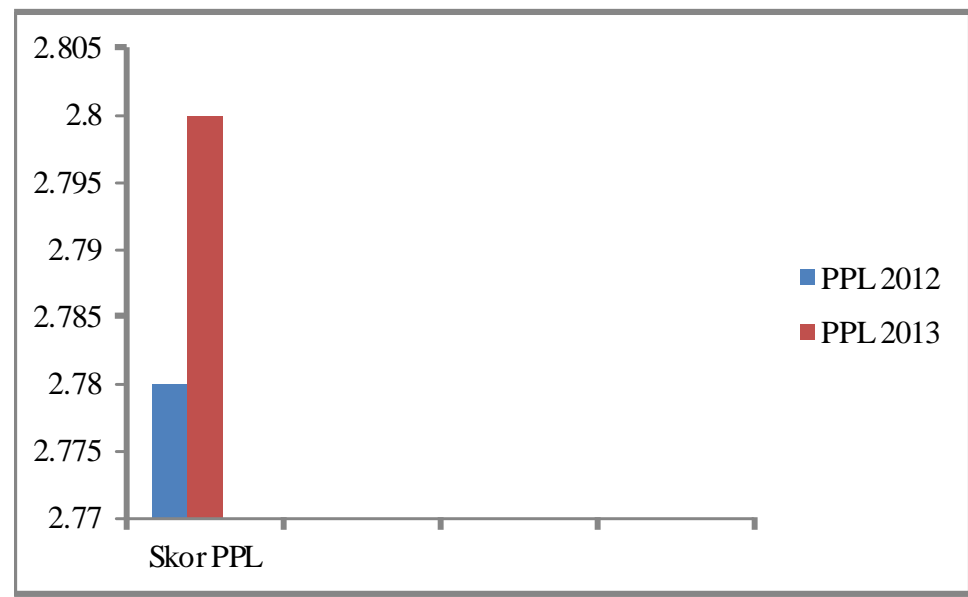

Gambar 3. Rata-rata Nilai Pelaksanaan Pembelajaran Mahasiswa PPL

Pembelajaran mikro juga tidak berdampak pada kualitas kegiatan PPL (Gambar 4).
Mahasiswa masih memiliki kelemahan dalam penguasaan materi, Penguasaan pembuatan 
SSP meningkat dikarenakan di sekolah mitra guru melakukan bimbingan intensif terhadap peningkatan kualitas SSP bukan karena pembelajaran mikro.

\section{Kesimpulan}

Berdasarkan hasil penelitian dan pembahasan yang telah dipaparkan, dapat disimpulkan bahwa peningkatan kualitas pembelajaran mikro tidak sekedar merubah model pembelajaran mikro yang telah dilakukan. Pembelajaran mikro membutuhkan matakuliah prasyarat keilmuawan maupun pedagogik yang baik. Penyelesaian secara komprehensif merupakan rekomendasi yang paling baik dalam meningkatkan kualitas pembelajaran mikro.

\section{Daftar Pustaka}

Arsal, Z. (2014). Microteaching and preservice teachers' sense of self-efficacy in teaching. European Journal of Teacher Education, Vol. 37, No. 4, 453-464.

Mergler A. G \& Tangen D. (2010). Using microteaching to enhance teacher efficacy in pre-service teachers. Teaching Education. (Vol. 21, No. 2, 199-210.

Donnelly R \& Fitzmaurice, M (2011). Towards productive reflective practice in microteaching. Innovations in Education and Teaching International Vol. 48, No. 3, 335-346.

Bell, N, D. (2007). Microteaching: What is it that is going on here?. Linguistics and Education 18 (2007) 24-40. Elsiver.

Kartal et al. (2012). Developing pedagogical content knowledge in preservice science teachers through microteaching lesson study. Procedia Social and Behavioral Sciences 46 $2753-2758$.

Spark R, L. \& Mc Callon E, L. (1974). Microteaching: Its Effect on Student Attitudes in an Elementary Science Methods Course. Science Teacher Education.
UPK. (2011). Pedoman Pembelajaran Mikro. UPK IKIP PGRI MADIUN. 